\title{
COMMUNITY ACTION: VALUE OR INSTRUMENT? AN ETHICS AND PLANNING CRITICAL REVIEW
}

\author{
Luca TRICARICO \\ Politecnico di Milano Dipartimento di Architettura e Studi Urbani, Dastu, Via Bonardi 3, Milano, 20133 Italy \\ Fondazione Giangiacomo Feltrinelli, Viale Pasubio 5, Milano, 20154 Italy \\ E-mail: luca.tricarico@polimi.it
}

Received 05 September 2016; accepted 20 April 2017

\begin{abstract}
The community concept has maintained a constant and growing interest in urban studies and many related fields. The origin of this continuing interest seems to derive from the importance of the concept of community within diverse forms of political language and interpretations within different planning practices. In this contribution, through the analysis of different ethical and planning theories, we want to provide an update framework on community action. According to this objective, the argumentation will proceed through a literature review on four ethics theories and three key aspects related to spatial planning, as well as matching this theoretical analysis with exemplifying practices. The final objective is to provide an original analysis on drivers and outcomes of different forms of community, raising general issues that refer to spatial planning, social organization and regulation.
\end{abstract}

Keywords: community, politics, city society, interpretation, local communities.

\section{Introduction: the concern for communities}

In recent years there has been an increasing interest in the debate on the role of communities in urban studies. Furthermore, the literature developed during these years reveals some particular aspects of this topic in relevant debates such as the definition of community development in planning (Phillips, Pittman 2014), the various views of local governance and localism (Davoudi, Madanipour 2015) and the different interpretations of the planning practices within the community action (Gallent, Ciaffi 2014). The origin of this continuing interest seems to derive from the importance of the concept of community within large and diverse forms of political language. Therefore, this interest seem to grow together with the crisis of participation in democratic systems, as the Economist Intelligence Unit (EIU 2015) "Democracy and its discontents" report suggests for the whole of western society $^{1}$ (the EU in particular) during the past five years. The diverse and new meaningful roles given by politicians to local communities also seems to derive from

\footnotetext{
1 Measuring the participation rate in General Elections over the last five years.
}

the critiques of central government and bureaucratic systems for their inability to respond to environmental challenges and social inequalities. This inability stems from a lack of freedom, which enables public policy to promote self-reliant initiatives (Sen 1990) based on the "ambitious" assumption that the needs of communities can be readily and broadly categorized and serviced remotely (Habermas 1984). We can briefly define these evident difficulties in public policies and planning models as the inability to reach a precise "object and subject" (Fainstein 2000). This political phase is thoroughly described by the geographer Erik Swyngedouw (2011: 372) as the "disappearance of the political", and also "the de-territorialization and de-nationalisation of bio-political relations, primarily as the result of growing nomadism and the explosion of multi-place networked identities". According to this definition, the community concept seems quite effective as a catalyst to re-establish legitimacy to the depleted public territorial action, as a "post-democratic" (ibid: 371 ) response of socio-spatial configuration.

In this way, the community concept progresses as a similar construct as the complex forms of community action, namely the drive of groups of individuals 
"to control and have responsibility for their own lives" (Gallent, Ciaffi 2014: 5). Different scholars and related research fields have analyzed these controversial aspects of community organizations and action in urban studies. In social policies, the community concept has been abundantly debated in recent years (Burrows et al. 2000). In particular, social policy scholars underline the emphasis of the community concept in the self-help and inclusion policy design and practices, related to public health provision, social housing and local welfare innovation. In terms of economic geography analysis, the community concept has often been identified as a node of new complex polycentric governance scenarios (Ostrom 2010). From this perspective, the different community units are leading to the disaggregation and decentralization of central state power, transferring responsibilities towards what some scholars identify as civil society (Cox 1999) while others refer to the phenomenon as voluntary aggregation of individuals creating a "spontaneous order" of spatial organization (Bladel 2005: 11). Due to this ambiguity in definition, communities have also come to be appointed as part of the "shift in neoliberal public governance" (Moore, McKee 2014: 521) and the retreat of the state from "the direct provision of public goods, welfare and services, and its devolution of autonomy and responsibility for these needs to active and empowered citizens and communities" (ibid). The concept also comes to play a role in local assets in contrast with the globalization process against what Sassen (2001) defines as the perverse dynamics of global cities with communities acting as a tool of empowerment for local markets and endogenous growth factors (Shaffer et al. 2004). Furthermore, they have been considered for their potential role in "bracing" social capital (Holman, Rydin 2004), a valuable process leading to the sustainability of local initiatives and trusted companion of local economic development policies (Dale, Newman 2010).

Taking into account this background, the objective of this work is to provide a theoretical contribution debating and remarking on two research questions:

First. How can we interpret community action combining ethics and planning theories?

Second. Which are the interests that mobilize community actions (values) and which different spatial planning aspects (scale and ownership) can help us to frame different practices?

In order to address these questions, the paper proceeds as follows: the Section 2 describes four ethical theories through which we can look at community action. Section 3 discuss on three concepts related to community action and spatial planning: values, scale and ownership. Section 4 concludes by remarking how different interpretations raise general issues that refer to spatial planning, social organization and regulation related to community actions.

\section{Methodology: ethics and community action}

Before discussing on the ethics theories we must establish a general definition of the concept of community action and its spatial dimension. This should be considered as the action of a collective unit of individuals toward a common goal, generally related to the improvement of the living conditions within their habitats or environments. In this sense, the improvement may be initiated through the:

- Affirmation of a shared moral imperative;

- Specific political and economic objectives.

In this contribution we aim to provide an original contribution on the ethical background of community organizations' spatial practices ${ }^{2}$ (Crosta 2010). This contribution does not intend to generalize about these complex social phenomena, nor to provide an exact prevision of a methodological approach. It also does not intend to define a priori the order within the practices of "community action", due to the fact that these are part of unpredictable forms of individual initiatives (Popper 1944; Hayek 1948). The possibility of realizing a general analytical framework can represent a misleading argument, unable to build replicable models, evaluations and indicators or predict consequential outcomes. The ethical reflection is important to deeper understand the strategic moves of community in spatial action. As Behnam and Rasche noticed (2009: 80), any "strategy process inevitably entails a way of reflection that is highly commensurable with the ethical reasoning process - no matter whether the strategist explicitly is aware of that or implicitly just follows the same procedures". A literature review on the different ethical interpretations on community action is relevant if we adopt a reformist perspective on spatial planning. In this contribution we want to consider the ethical interpretation as an alternative of the orthodox vision given by the normative and prescriptive dimension of communities and social aggregations. For planning scholars, the adoption of different lens of analysis on community action can represent a tool of interpretation on changes occurring in the relationship between space and society and consequently a certain relationship between state and society. Through the review of specific ethics theories, we can therefore observe the connections between certain conditions of community action: a priori values, "enabling" policies or regulative frameworks. For these reasons, and for requirements

\footnotetext{
2 Other contributions adopting a similar methodological appro-
} ach have been experimented by Moroni (1997) and Beatley (1994). 
related to the length of the present discussion, we want to consider the communitarian, the utilitarian, the libertarian and the geo-anarchist theories.

\section{Communitarian}

The first community action interpretation we want to consider is that provided by the communitarian theory $^{3}$. This theory was the first to emphasize the connection between individuals and community. Between the slightly varying contributions of this thought, the common point is the affirmation of the community as a paradigm of shared values, as the origin of community rights and "communal responsibilities". From these form a common knowledge that derives a coercive force in the use of "communitarian" goods from the individual members of a community. The shared goods that also represent the community boundaries include natural resources such as: "soils, waters, plants, and animals, or collectively: the land", namely as a part of what ecologist scholars defined as "biotic communities" (Leopold 1949: 865-866). In this sense, the definition of a community can be variable according to different dimensions, considering the scale of a family, political state or nation. Therefore, the concept of community assumes a primary role in the construction of the ethical theory, as the shared conception and substantive way to develop the moral values of individuals. According to Moroni (1997: 183) within this theory, the "idea of community" pretends to be seen as the shift from the atomistic perspective typical of the liberal society. The community concept is also able to invert the liberal rationales on the priority of rules rather than virtues. According to communitarian, the virtues are the communal elements on which the collective identity is based (MacIntyre 1984), the central element in the moral experience of individuals. With this perspective, communitarian theory intends to abandon the deontological ethic to adopt a radically teleological one, underlining the importance of the $a$ priori shared common understanding of the "good life".

\section{Utilitarian}

Beyond the differences that separate the various versions of utilitarianism ${ }^{4}$, the three key areas are:

\footnotetext{
3 Communitarian theories represent an important strand of contemporary ethics. The most important references of this ethical theory can be found in the works of Etzioni (1994), Sandel (1982) and Unger (1976).

4 Utilitarianism has been for long time the most relevant and explored research of modern western political philosophy. The classic formulation of utilitarianism was originally established by the works of Bentham (1970) and developed later by other authors including Jhon Stuart Mill (2010). With Pigou (1920) stating that this theory is applicable in economics, in the calculation tools of collective utility, such as cost-benefit analysis.
}

1) Consequentialism, namely the idea that actions are evaluated on the basis of the state of things that follow. According to this concept, spatial action can be judged depending on the consequences it produces on the present state of things.

2) Welfarism, namely the assessment and evaluation on the change of the state of things expected from a spatial action. This is taken as a result of the information on the utility that accompanies it. The utility does not coincide with the individual's pleasure or happiness, but as the maximization of preferences between a group of individuals.

3) Sum-ranking, namely the assessment tool for calculating the maximization of collective utility preferences.

The utilitarian theory is based on the principle of the autonomy of individual preference, which recognizes the supremacy of the individual in the evaluation of his/ her welfare and therefore of their usefulness. According to the principle of the constructive model (Harsanyi 1979), individuals are addressed not only on personal preferences, but also from the moral preferences that lead individuals to move towards a collective behavior and action. Despite different social positions and different levels of well-being, the moral value becomes the guide for individuals to act rationally. The resulting action of the community is to encourage the social situation that ensures the highest level of average utility in society. Particular communities, made of a collective of individuals and diverse social positions, are also driven by interpersonal utility comparisons (ibid) This comparison allows individuals to adopt impartial and sympathetic point of views, abstracting their own personal preferences, entering a process of imaginative empathy. In this way you can compare the usefulness of different individuals according to a community database.

\section{Libertarian}

The libertarian idea of community is rooted in the belief that individuals are endowed with inherent rights to their existence that must be considered as universal, primarily as moral rights and then as legal rights 5 . Among the various theories, the contribution of Nozick (1974) could be considered as the more interesting one when applied to land use issues and spatial action of communities and individuals. The main assumption of this theory is that

\footnotetext{
5 Libertarian ethics are rooted in the evolution of natural law theories, see for instance the works of Von Pufendorf and Hert (1715) and Locke (1690). Among the various authors who have drawn recent versions of theory of rights we must consider Hayek (1960; 1988), Nozick (1974), Dworkin (1977) and Pollock (1996).
} 
the individuals are custodians of inviolable rights, independently from any social organization. These rights can determine the external environment of each individual and fix the abilities lawfully available. In this sense, individuals do not represent resources available to society in general, but for themselves. There cannot be a "social entity" above individuals able to interpret and draw the collective benefits. This organization cannot happen without a concrete action formulated by individuals, characterized by substantial differences and separateness in the intentions and plans for their lives (Nozick 1974: 36). The position of this thesis is anti-consequentialist, namely taking a point of view that is indifferent to the results of collective actions in the final states of things (Moroni 1997: 76). In Nozick's view, the property rights are the most important rights and a model for all others. Compared to the geo-anarchist theories (presented below) the classical libertarian theory still supports a certain type of social organization with a better formula for maintaining individual rights as compared to anarchy (Nozick 1974: 3-5). In the analysis developed about the state of nature, Nozick points out the role of mutual aid associations as a solver on the disputes between individuals, describing them as a form of protective associations of individual rights. Within these, the dominant protective association will emerge as a natural monopolist in a given geographical area. The task of this specific association is to efficiently manage conflicts and assure the respect of individuals' rights. The dichotomy between independent individuals and the dominant protective association is also known as the concept of minimum state. A minimum state is one that protects those individuals that finance it voluntarily according to the principle of compensation, namely to compensate for the disadvantage caused to anyone for performing activities that may prove detrimental to others. The key concept is the independence of individuals to participate or not in supporting the dominant association, having in both of the cases the security of fundamental rights recognition and acceptance of the performance of minimum justice guaranteed by this recognition.

\section{Geo-anarchist}

To understand what Geo-anarchists intend as a community, we must first establish the classic distinction between the public sector, that which is authorized through the use of coercion, and the private sector, the sector characterized by voluntary actions ${ }^{6}$. As defined by Moroni (2010: 7), "in the first case the key

\footnotetext{
6 Among the authors who have dealt with this there are the theoretical contribution on the relationship between public goods and private communities proposed by Foldvary (1994) and the latest private residential communities (Nelson 2005) and contractual communities (Brunetta, Moroni 2012).
}

elements are characteristic of sovereignty, authority and one-sidedness of the law; in the second, the consensual, equality, multilateralism, the contract". The geo-anarchist theory describes communities solely as a contractual expression typical of the private sector in combination with spatial-based formulas to which members adhere voluntarily on the basis of a unanimously signed contract. The term geo-anarchist derives from the vision of a society organized as a polycentric group of voluntary and contractual communities, "based on sovereign individuals" (Foldvary 2001: 404). In the theory of Fred Foldvary (2001), this vision is that of complete decentralization of powers within a cosmos of "voluntary cities" formed by small groups or individuals and families. According to this view, the distinction between the government and private sector would disappear as "voluntary governance it would be based on contracts among private members and property owners" (ibid). Foldvary's criticism of the centralization of public governments derives from his analysis of Austrian public choice theories and Governance Structure, based on the fundamental aspects of "decentralized nature of knowledge, the subjective nature of values and preferences, the disaggregation of phenomena, [... ] the analysis of spontaneous order and the productivity of roundabout investment [...] " (Foldvary 2002: 162).

\section{Value, scale and ownership: three crucial concepts}

The interpretations on the concepts like value, scale and ownership can help us to describe the specific motivations and outcomes that can drive community towards an action or spatial initiative.

Value could be seen as:

- intrinsic or a priori, a constitutive aspect shared by all community members;

- extrinsic, a tool to achieve the aggregation of preferences within the policy process and/or as an expression of individuals' freedom through a logic of mutual objectives and contractual community agreements.

The scale concept describes the spatial limit that communities have regarding their values. Different interpretations and observations in practices reveal how different spatial demands or issues of a community can define (or not) the boundaries of a specific geographical area. The scale can range between local communities, transactional or virtual, with or without connotations and requires reinforcement through a spatial proximity.

The definition of the role of ownership shows how and why communities need to own specific assets as 
well as how and why ownership schemes are organized due to differing objectives are vital components. The role of ownership is a crucial aspect identifying the shift from motivation to practices, determining substantially the results of the action of local communities. This factor is also important in understanding the connection between community actions and the regulatory framework of certain activities and organizations.

\section{Values}

The discussion on values within community action proposes to respond to the question: what are the features and specific interests that propel community initiatives? As mentioned in the previous section, we intend to divide the community value of community action into two groups (Fig. 1): community as intrinsic value and community as extrinsic Value.

Community as intrinsic value. It is a concept strictly linked to the communitarian theory that consider the relational dimension and the moral imperative of community existence. It overshadows both the individual dimension and the community as an instrumental tool of spatial action. The construction of shared values is seen as the primary driver of community action. The path of intangible assets construction is the basic requirement for any form of action, starting from community values. The instrumental (or extrinsic) action follows only as a second step as an outcome of the main process of identification and affirmation of a community's intrinsic values. In brief, every intrinsic value produces an extrinsic action, but this must never be considered as the fundamental imperative of the community. For instance, extrinsic values of Eco-villages can be considered according to a communitarian-based choice "to live together with a common purpose, working cooperatively to create a lifestyle that reflects their shared core values" (Kozeny 1995: 18). The features of an intrinsic value of a community are explained in depth in the contribution of Shiell and Hawe (1996: 242) "community relations are a feature of individual identity and well-being. Community means more than association or shared location. It also means more than the inclusion of interpersonal effects (externalities) in the individual's utility function. The intrinsic and not just the instrumental value of social relationships is important". Furthermore, life of individuals included in an intrinsic value community is encompassed in a common framework of the shared values. In Ecovillages, the ecologist and "biotic community" theory (Leopold 1949) is reflected in the use of "green building techniques, for example, constructing buildings that are made from earthen materials, and situate housing units around green space for subsistence gardening.
Villages are purposefully laid out to maximize utility from the environment and to diminish excessive use of resources as well as to foster community interaction" (Ergas 2010: 34).

Community as extrinsic value. In these groups of communities are also included the community actions defined by ethical theories that strongly consider the role of individuals, as single entities with distinctive values, independently formed. Starting from this assumption, the community must be considered an extrinsic tool with two separate kinds of expected results:

First, (considering the utilitarian approach) the community represent an aggregation of preferences and inter-personal comparison of utilities, performing as a tool capable of meeting the different objectives between individuals (Harsanyi 1979). The action in this case aims to produce consequential outcomes, such as the implementation of policies or introduction of new forms of urban governance. The community action is moved to target individuals' common interests and preferences, producing advocacy for political empowerment. Social capital can also be considered a key resource in this first definition of extrinsic community as an enabling tool of collective action (Rydin, Pennington 2000). As defined by Ostrom (2000: 176), social capital "is the shared knowledge, understandings, norms, rules and expectations about patterns of interactions that groups of individuals bring to a recurrent activity". With these operations, communities can valorize the organization of human and physical capital, helping individuals to "coordinate activity and credibility commitment (...) to a sequence of future actions" (ibid).

Second (considering libertarian and geo-anarchist approaches) the community represent the outcome of voluntary agreements or contractual formulas between private individuals, taken as a collective action for economic empowerment and self-organization objectives. The priority of these initiatives have been defined in what Jacobs (1961) and Hayek (1988) described as "spontaneous order" of spatial organization. A purely voluntary approach in the geo-anarchist perspective (Foldvary 2001: 404) sees community organization operating in two ways: evolution or devolution. The evolutionary method consists of the contractual adhesion of single individual households into an association for providing services for the members. This approach is suitable for a local scale consisting of a few households. In this case, a governing body can be elected by the members, delegating some authority to the board. The main task of this authority is to separate private and collective goods and provide local services funded by its members. The devolution method consists of the transfer of political 
authority, property and programs to a lower level of governance. This approach consists of the broad idea of recognizing neighbourhood association coalitions as a new and separate jurisdiction. Besides the phenomenon of private cities nowadays diffused throughout India and China (Rajagopalan, Tabarrok 2014), an interesting example on the devolutionary approach is represented from the case of the voluntary city of Reston (Virginia). This census-designated place (without any local public administration) contains contractual and private schemes of governance comprised of a coalition of homeowners associations with 50.000 inhabitants and 24.000 dwellings (Foldvary 1994).

\section{Scale}

The definition of a specific scale of community action aims to respond to the question: Which community spatial scale do we refer to when we talk about community action? We can summarize this concept in relationship to either single or intertwined aspects: as either a consequence of issues and opportunities related to residential proximity or as the product of active exchange across social networks and cooperation within local political and economic dynamics.

For communitarians we cannot consider the community as a static concept or set of relationships arising from casual residential proximity without any type of defined motivation. The actions of the community are defined by individuals' common values. According to Delanty (2003), the definition of community boundaries has an indefinite nature that cannot be matched to a particular group or place, but to a particular size and ideal interpretation. By examining local action in communitarian organizations, the scale of the community can be defined by a common fellowship or community of relations or feelings (Levinson, Christensen 2003). In this case, the connections within a community organization can represent an informal network formed by different individuals, specific groups and organizations who identify themselves in a network of interdependence regarding a common set of responsibilities (Gilchrist 2004; Brint 2001). The procedure to define a network of agreed shared values and mutual understanding can take considerable time and effort and the employment of expert facilitators, such as community organizers (Stein 1986). In this vein a relevant example in determining such networks (also as a political movement) are through the activities developed by the Association of Community Organizations for Reform Now (ACORN), an international coalition of community-based organizations that advocate for low and moderate income families by working on neighborhood safety, voter registration, health care, afford-

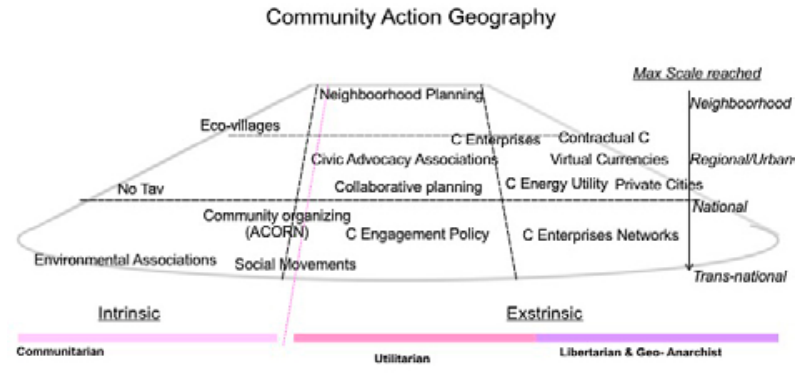

Fig. 1. A scheme of community action geography according to values and maximum-scaled reach for single action typology (elaborated by the author)

able housing, and other social issues (Rathke 2009). At its peak ACORN had over 500,000 members and more than 1,200 neighbourhood chapters in over 100 cities across the U.S., as well as in Argentina, Canada, Mexico, and Peru (Farrell 2009). In the ACORN experience difficulty of maintaining a large-scale network of "shared values" is evident when looking at the causes of the ruinous end of the experience of their experience ${ }^{7}$.

In a utilitarian perspective, community scale can also be considered from a prescriptive and normative dimension, according to a specific planning level or policy in a localist agenda. In this way different scales of community arise as an aggregative tool for a plan-making and decision-making process, with the objective to improve certain policy outcomes. In this group we can frame the practices of associative action in urban planning (Messaoudène et al. 2014) associated with the intent of local level political empowerment. With this idea over the last several decades we've observed an intense season of public policies arising with the aim of matching urban planning and transformation with local communities' involvement. The community scale in this view has been defined by interests, also interpreted as an advocacy tool to lead towards participation in the planning process (Davidoff, Reiner 1962; Davidoff 1965). According to Balducci (1991: 158), the objectives can also be related to the improvement of planning effectiveness: through specific community engagement policies, depending on the proper representation of needs and social demand, or as a way to enable engagement of weak community groups (in terms of political and economic power) in policy-making. Some scholars interpret the scale of the "interests network" as a variable due to the nodes of aggregation of social

\footnotetext{
${ }^{7}$ It was the involvement of some members in irregular funding The community scale can also be considered from a political and normative practices that led to the dissolution of the group in 2010. On March 010, the ACORN national organization's board decided to close remaining state affiliates and field offices by April 1 due to falling revenues (Smith 2010).
} 
capital in terms of close relationships between people that are keen to achieve common goals. Regardless, it is generally accepted that the "conditions for this to happen are quiet extreme (...) in procedural terms but also in terms of expectations of the actors involved" (Rydin 2014: 32).

In between utilitarian and libertarian perspectives we can observe practices related to asset-based community organizations and enterprises (Tricarico 2016; Bailey 2012; Aiken et al. 2011). Following Somerville and McElwee's definition (2011:319) of the term "enterprise", we refer to "an activity that produces or aims to produce value that can be expressed in monetary terms and any individual that is responsible for producing such value is commonly called an "entrepreneur". The scale of this enterprises is linked towards "community" trading systems with a strong social purpose in relation to a defined population or sub-group living in a geographically defined area (Bailey 2012: 4). The social purpose is what social enterprises theorists like Pearce (2003: 25) defined as "engaging in trade in the marketplace; not distributing profits to individuals; holding assets and wealth in trust for community benefit; democratically involving members of its constituency in the governance of the organization; being independent organizations accountable to a defined constituency and to the wider community". This is for instance the case of Development Trusts in the United Kingdom (Le Xuan, Tricarico 2014), legally registered as third sector bodies: Charities, Community Interest Company (CIC), Industrial and Provident Society. Development Trust activities are self-sustaining through acquiring assets to enable growth and income-generating streams to support other social functions. They are also often engaged in local and national trading operations or contract income, all financial surpluses generated enable greater operational autonomy and are applied to the social objectives of the organization and the community projects it runs/supports. The quality of services delivered is managed at the Trust level and are monitored through reporting procedures. CIC and charity regulators control the social and community accountability of the activities. According to Di Domenico et al. (2009) "Development Trusts are embedded in social entrepreneurship, a paradox given that this kind of entrepreneurship is being promoted as a 'solution' to social and economic problems often caused by market failure". This idea follows the shift towards "community" politics as an important component of civil society, a marked trend that some commentators have included in the broader concept of the "Third Way" (Giddens 1998), where community enterprises make up a relatively small part of the social economy.
According a more focused geo-anarchist perspective, we must take into account other kinds of community actions, defined by certain literature as contractual communities (Brunetta, Moroni 2012). The Members join these communities on the basis of a contract (or agreement) that is unanimously accepted in light of the expected benefits. The contract establishes a set of commitments and rights for the members. Within the commitments there is the respect of rules of cohabitation (such as the rules in land use and prescription of private and collective spaces, behavioral and other general rules). There is also the obligation to pay some form of monetary contribution (or supply a service) to ensure the proper functioning of the contractual community itself. Within the rights there is the availability of goods and the provision of collective services. Contractual communities are scaled both by hardware (such as buildings, spaces, goods) and software (such as rules and organization). According to MacCallum (1970) the bases to form a contractual community (and so defining the scale of action) relies on: (i) a group of individuals with one ore more common interests, (ii) a territory with identifiable boundaries, (iii) an integrative system of organization that regulates the activities required for the community's operation and continuity. These three aspects explicate in a binding agreement; that is, via a voluntarily accepted contract. According to Brunetta and Moroni (2012), observation of local contractual communities practices follows three approaches: leasehold with a single owner who rents through a contract to a community of tenants, such as shopping mall or hotels; freehold as a coalition of multiple owners that manages common spaces and services, such as homeowner associations, cohousing or condominiums; commonhold as collective ownership (mostly cooperatives) that entails privileges and duties for the members in regard to the use of property, such as housing cooperatives and certain forms of collective private ownership of natural resources ${ }^{8}$, the so-called "commons" in Ostrom's usage (1990). Another relevant reflection at the scale of contractual communities can be carried out by analyzing particular practices of "virtual local currencies" not only as relational networks of economic action or institutional laboratory but also as a spatial action factor. The case of Sardex is an interesting experience of a regional Local Exchange Trading and Credit Scheme between small enterprises and the local financial institutions of the Italian Region of Sardinia. The motivation came from what they define as the idea that "enabling proximity-based and trust-based

8 Two related Italian examples are the so-called "Regole" in Cortina D’Ampezzo and the Cento "Partecipanze" (Minora 2008). 
relations" foster "economic empowerment of a defined local territory; creating a resilient and vibrant community; and defining a more equitable environment for trading" (Littera et al. 2014: 5). This goal of economic and political empowerment enables a certain virtual scale of community through a credit unit that is not convertible into any other currency. It can only be spent and acquired through the members who voluntarily accepted the rules of the scheme in a "digital" field of action. This field also issues mutual credit without interests along with many tools and services provided to the network by the network service provider (e.g. brokering, business networking events, community management, online services, helpdesk) (ibid). These types of community action overcome the traditional framework of public and large private financial institution allowing a virtual community of entrepreneurs to self-organize financial transactions and promote investments in a defined geographical area ${ }^{9}$.

\section{The role of ownership}

The definition of the role of ownership by community members is a crucial issue significantly dividing different types of local action. In considering the role of ownership, the dichotomy of property of goods and the relational dimension of community values is intertwined significantly in relation to the role and the resulting configuration of the space where the action takes place.

In a communitarian perspective, property takes a secondary role and the concept of "common good" is emphasized as the ideal. From this perspective, the concept of ownership is closely linked to the negative consideration of concepts like individuality, autonomy, personal aspirations and prevailing aspects in the other kinds of actions. The virtues and moral rules of the community totally disregard the formulas of property, which become exclusively instrumental in their affirmation. An interesting example of this role can be clearly observed in the management formula of Prinzessinnengarten in Berlin (Kreuzberg). The current organization promotes community action from an "idealist motivation" concerning issues such as the preservation of green areas of the city, the ecological education and the fight against gentrification of neighborhoods the city center and the promotion of urban agriculture with the aims of social inclusion. The free access community garden is a space that Bendt $e t$ al. (2013: 28) defines as a generator of a "sense-of-place and experiential learning about local ecosystems",

\footnotetext{
9 Currently (2014) the community is made of more than $2 \mathrm{~K}$ enterprises and $85 \mathrm{M}$ euros of economic transactions (www.sardex.net)
}

representing "arenas or environmental learning in cities". Over the years, the community leaders of this space have set up agricultural activities in a mobile formula through the use of mobile pots and a number of caravans and prefabricated transportable units. This choice stems from the concern that when, and if, Berlin's local government would decide to revoke the authorization to use the public land, they can easily relocate elsewhere, remaining independent from the potential confines of the current location. Other examples of community as an intrinsic value are those that have been defined in some American literature as eco-villages (Christian 2007: 29; Dawson 2006). These communities are organized in nomadic or permanent situations, often settling in residual areas or geographically remote from cities and inhabited areas. Individuals wishing to join must be willing to accept values and rules arising from a strong communitarian and ecologist matrix. In these types of communities there is no private property and the location corresponds to the availability to use spaces that allow them to develop their community-based ideals of life undisturbed. The role of ownership in organizations of this kind is particularly important when operating at a larger scale such as with environmental associations and social movements. For movements like "No Tav", for example, the control (not ownership) of the land becomes the intrinsic value of the community. A genuine process of collective identification with a particular intended use of the territory stems from the special values shared by the community and is essential to the collective welfare (Fedi et al. 2012). In this way, the community stands in conflict with the public power and to the principle of the general interest linked to strategic national infrastructure projects such as highspeed rail networks for example (Greyl et al. 2012). An opposition to any form of dialogue to government action often follows and a consequent antagonist action of local presidium. The land, or at least this specific idea of land ownership, even if not claimed as a community property, is claimed as an intrinsic driver of community belonging and value.

According to the theories based on extrinsic community value (utilitarian, libertarian and geo-anarchist) community action can refer to an ownership role that can be defined as a "commonhold contractual community" (Moroni 2014: 45) or as Ostrom (1990) simply suggests, the "commons". In this sense, Moroni (2014: 46) recognizes a relevant issue related to the usual interpretation of commons as a different kind of property or as a third alternative to public and private property. This seems true only if we consider private property as a kind of property always owned 
by a single individual for his or her sole use. But this is a misconception: community ownership can take very different forms, including several kinds of collective private property. The literature has generally considered private properties as "a kind of property always owned by a single individual for his or her sole use" (ibid) without taking into account the different forms and particular management schemes and rules of their use. In the survey and research by Aiken et al. (2011) on "Community based organization controlling asset" it can be seen that a large number of these organizations base their activities in owning or controlling assets as collective properties. Within these organizations are included village halls, development trusts, settlement and social action centers, community centers, community farms, community land trusts, arts/cultural centers, sports centers, community wind farms, community shops, religious or faith centers, preservation or heritage trusts, advocacy and advice centers, park trusts and housing co-operatives. A surprisingly large number of respondents (63\%) "indicated that they fully owned their most significant asset, while (19\%) reported that they were leasing or renting it". This report indicates that, in addition to the current policy attention to asset transfer in certain countries like UK, there is a pre-existing cohort of organizations active in the field of contractual and collective private ownership schemes. This result would also be consistent with the historical studies that the research refers to (Woodin et al. 2010).

In recent years, the role of different "forms of community and mutual ownership (...) are still in existence and available today. Managing, sustaining and developing this older stock represents an important issue that requires further consideration". Furthermore, looking at the property purposes declared by these community organizations ${ }^{10}$, only a part of these explicitly state the concept of "enhancing social well-being" (Fig. 2). Some of the other highest responses regarding the purpose of the organizations in terms of the aim of asset ownership underline the importance of other aspects like: "general community uses"; "offering a base for the activities of other organizations"; "housing our organization's activities"; and "providing office/administrative space for our organization". A significant example of extrinsic community action that should be considered in the discussion of the role of ownership is that in charge of developments and management of local energy systems. These organizations appointed to manage new initiatives are an entirely new gamut of opportunities in collective energy production and management. The

10 Answering a specific question on the purposes given by organizations for the different owned assets.

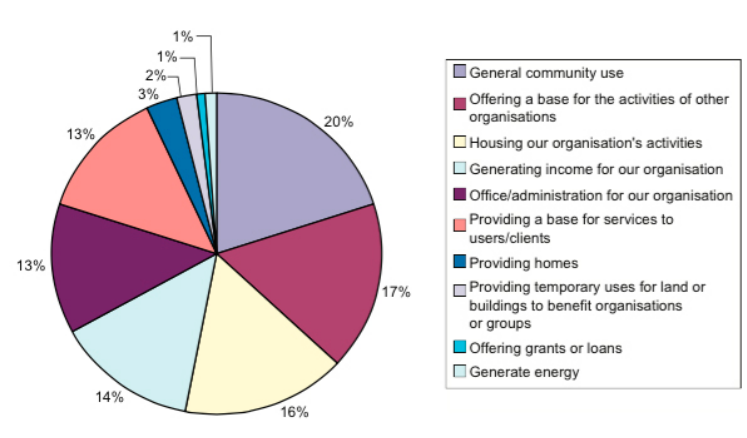

Fig. 2. Community asset and purposes according to JRF survey on CBOs (Aiken et al. 2011)

nodes of this new polycentric system of energy production will not be - solely and merely - individual homes, stores, or industries (as is often considered, also in terms of new legislative measures: "Contemporary policy makers commonly approach energy demand issues with an individualistic model of attitudes and choice": Goulden et al. 2014), but also in new forms of "intentional communities" and "voluntary communities" (Brunetta, Moroni 2012). Whilst in the traditional centralized energy system, demand and supply occupy separate spheres; here they are in direct connection. Clearly, this smart grid does not need to be a public utility; nor need it be unique or universal. We can imagine a situation with myriads of micro-grids working in parallel with wider grids or running in isolation (i.e. in a totally separated way: "islanded"). Such a scenario does away not only with alleged intrinsic reasons for a "natural" monopoly of energy production, but also with the idea of natural distribution monopolies. We should consider these community energy enterprises as "community technology" namely as a sub-category of "social technology" that "denote dependable expertise in voluntary social organization and exchange" (Lowi, MacCallum 2014).

\section{Concluding remarks}

Looking at the framework of community actions reported in the analysis, we can make a series of useful reflections to understand how these features allude to a specific interpretation of both the background of a particular social organization as well as the policies and rules designed to enable action.

First of all, it must be repeated that none of the practices framed has characteristics definable as "replicable models" or belong to a specific group of features carried out from the examples mentioned. This is impossible because:

- On one hand (as stated above) it is necessary to assume and emphasize that each initiative belongs to a particular place and individuals with specific 
peculiarities. These are unpredictable, not replicable and do not belong to groups that may be exactly categorized.

- On the other hand, the objective is to explore the "community action" topic with no pretense of producing exemplary methodological tools, an aspect that in the same vein Popper (1944) underlined as a general social sciences bias: the impossibility to "determine trends" because the analysis could be affected by relativism and therefore unable to induce "social change" and create effective tools of planning.

According to this premise, the analysis of the literature and practices of intrinsic and extrinsic community actions seem to meet different issues.

First. The limit of shared community values as a fundamental and irreplaceable ingredient of a just "social action" ignoring the private sphere of individuals and families, as well as the importance of individuals' preferences, wishes, resources and dynamic expectations. This is true when observing some radical communitarian practices like eco-villages and social movements in a local scale, but also with some environmental associations or communitarian-based coalitions (as discussed above regarding ACORN). According to communitarian theories, instrumental political or economic tools of extrinsic action are blind to the fundamental importance of "full participation in political community for the good life of human being" (Buchanan 1989: 852).

Second. The limit of avoiding the crucial debate on democratic "social choices" and the importance of pledging equal capabilities within communities and individuals (Sen 1990). The simplification through the imposition of "communal values" within community members underrates the compatibility and conflict issues of wicked problems (i.e. land-use, climate change, infrastructure planning; Lindblom 1959; Geissler et al. 2017). These issues raise widely discussed, yet complex questions within the debate of public and collective choices in planning. These aspects have been mostly disregarded by communitarian theories and practices, applying a radically teleological critique, forsaking reflection on what might be the correct strategy in a given territory, but moves instead to the search for what must be done to assure "shared" practice of the good life.

Third. The importance of neutral communication and precise objectives of extrinsic community actions, thereby putting more emphasis on the knowledge based community agreements like contracts or entrepreneurial organizations. This approach is true for the extrinsic use of community relations, in order to enforce the action through the explicit statement of why and how communities move and for which specific advantages. This basic principle for effective "social choices" in community action leads to acquire knowledge for the selection of irrelevant or more or less important actions or strategies (see for instance Sen 1977). In this sense, we can consider the political empowerment of extrinsic communities biased: It is not convincing that communities can be an effective product of a common framework within individuals' desires and expectations and produce an exact tool of preference aggregation. In the same vein a point to be stressed is also that extrinsic community actions purpose can can be both for-profit and non-profit. There is no inherent reason that requires community ownership to be a "third party", "non-profit" body (as some instead seem to believe). The distinction between forprofit and non-profit is not as important as has been maintained; in both cases, the extrinsic community actions can be considered as voluntary and entrepreneurial action within the civil society (Beito et al. 2002). The idea itself of entrepreneurship is not necessarily tied to the profit of single individuals; it can regard any type of activity, including group activity (Cato et al. 2008). Many misunderstandings have resulted from a certain use of the term "community". Often used by community development studies the concept of "community" creates confusion because in many cases it is used, not as a descriptive concept, but as a value-laden one identifying something that is "good" in and of itself. In this sense, extrinsic community actions like community enterprises are "communities of choice" or "intentional communities", not "communities of chance" or "community of fate", but are "rule-bound communities" (Moroni 2014).

Fourth. The knowledge limit of extrinsic communities based on private individuals' contractual agreements. The action promoted by these agreements can on the one hand seem particularly legitimate, while on the other seem to underestimate the different functioning of a plurality of groups (i.e. informative and economic disadvantages). The aims of "insulated" voluntary communities avoid the issues associated with a deep knowledge of external communities' aims and needs. This lack of information can represent a potential conflict within a self-organized polycentric spatial distribution of communities. If the priority of community action relies solely on negative freedom within a group of individuals, it can result in a failure to promote social interactions between different groups. As Ostrom (2010: 659) underlined, "the assumption that individuals have complete information about all actions available to them, the likely strategies that others will adopt, and the probabilities of specific 
consequences that will result from their own choices, must be rejected in any but the very simplest of repeated settings". Furthermore, even if we accept contractual communities as an effective tool of action regarding individuals' economic empowerment and freedom, we cannot ignore the dependency of these factors with global conflicts of contemporary societies (Dahrendorf 1988). In this sense the distributive principles are also relevant for an approach based on individuals' freedom; the conflicts between interests, efficiency and equity; all aspects that community organizations and society as a whole must cope with and not avoid.

\section{Acknowledgment}

I would like to show my gratitude to Stefano Moroni for sharing his precious suggestions with me during the course of the research.

\section{References}

Aiken, M.; Cairns, B.; Taylor, M.; Moran, R. 2011. Community organisations controlling assets: a better understanding [online], [cited November 2015]. Joseph Rowntree Foundation. Available from Internet: https://www.jrf.org.uk/report/ community-organisations-controlling-assets-better-understanding

Bailey, N. 2012. The role, organisation and contribution of community enterprise to urban regeneration policy in the UK, Progress in Planning 77(1): 1-35.

https://doi.org/10.1016/j.progress.2011.11.001

Balducci, A. 1991. Disegnare il futuro: il problema dell'efficacia nella pianificazione urbanistica. Il Mulino.

Beatley, T. 1994. Ethical land use. Baltimore: Johns Hopkins U.P.

Behnam, M.; Rasche, A. 2009. "Are strategists from Mars and ethicists from Venus?" - strategizing as ethical reflection, Journal of Business Ethics 84(1): 79-88. https://doi.org/10.1007/s10551-008-9674-7

Beito, D. T.; Gordon, P.; Tabarrok, A. 2002. Toward a rebirth of civil society, in D. T. Beito, P. Gordon, A. Tabarrok (Eds.). The voluntary city. Ann Arbor. The University of Michigan Press.

Bentham, J. 1970. An introduction to the principles of morals and legislation. London: Athlone Press.

Bendt, P.; Barthel, S.; Colding, J. 2013. Civic greening and environmental learning in public-access community gardens in Berlin, Landscape and Urban Planning 109(1): 18-30. https://doi.org/10.1016/j.landurbplan.2012.10.003

Bladel, J. P. 2005. Against polanyi-centrism: Hayek and the re-emergence of "spontaneous order", Quarterly Journal of Austrian Economics 8(4): 15-30. https://doi.org/10.1007/s12113-005-1001-x

Brint, S. 2001. Gemeinschaft revisited: a critique and reconstruction of the community concept, Sociological Theory 19(1): 1-23. https://doi.org/10.1111/0735-2751.00125

Brunetta, G.; Moroni, S. 2012. Contractual communities in the self-organising city: freedom, creativity, subsidiarity. Springer Science \& Business Media. https://doi.org/10.1007/978-94-007-2859-2
Buchanan, A. E. 1989. Assessing the communitarian critique of liberalism, Ethics 99(4): 852-882.

https://doi.org/10.1086/293124

Burrows, R.; Nettleton, S.; Pleace, N.; Loader, B.; Muncer, S. 2000. Virtual community care? Social policy and the emergence of computer mediated social support, Information, Communication \& Society 3(1): 95-121. https://doi.org/10.1080/136911800359446

Cato, N. S.; Arthur, L.; Keenoy, T.; Smith, R. 2008. Entrepreneurial energy associative entrepreneurship in the renewable energy sector in Wales, International Journal of Entrepreneurial Behaviour \& Research 14(5): 313-329. https://doi.org/10.1108/13552550810897678

Christian, D. L. 2007. Finding community: how to join an ecovillage or intentional community. New Society Publishers.

Cox, R. W. 1999. Civil society at the turn of the millenium: prospects for an alternative world order, Review of international studies 25(01): 3-28. https://doi.org/10.1017/S0260210599000042

Crosta, P. L. 2010. Pratiche. Il territorio "è l'uso che se ne fa". Milano: Franco Angeli.

Davidoff, P. 1965. Advocacy and pluralism in planning, Journal of the American Institute of Planners 31(4): 331-338. https://doi.org/10.1080/01944366508978187

Davidoff, P.; Reiner, T. A. 1962. A choice theory of planning, Journal of the American Institute of Planners 28(2): 103-115. https://doi.org/10.1080/01944366208979427

Davoudi, S.; Madanipour, A. (Eds.) 2015. Reconsidering localism. London: Routledge.

Dawson, J. 2006. Ecovillages: new frontiers for sustainability. Schumacher Briefing (No. 12). Chelsea Green Publishing.

Dahrendorf, R. 1988. The modern social conflict: an essay on the politics of liberty. University of California Press.

Dale, A.; Newman, L. 2010. Social capital: a necessary and sufficient condition for sustainable community development?, Community Development Journal 45(1): 5-21. https://doi.org/10.1093/cdj/bsn028

Delanty, G. 2003. Community: key ideas. Abingdon, Oxon, UK: Routledge.

Di Domenico, M.; Tracey, P.; Haugh, H. 2009. Social economy involvement in public service delivery: community engagement and accountability, Regional Studies 43(7): 981-992. https://doi.org/10.1080/00343400701874180

Dworkin, R. M. (Ed.) 1977. The philosophy of law (Vol. 102). Oxford: Oxford University Press.

Economist Intelligence Unit (EIU). 2015. Democracy Index 2014 Democracy and its discontents [online], [cited November 2015]. A report from The Economist Intelligence Unit. Available from Internet: http://www.sudestada.com.uy/ Content/Articles/421a313a-d58f-462e-9b24-2504a37f6b56/ Democracy-index-2014.pdf

Ergas, C. 2010. A model of sustainable living: collective identity in an urban ecovillage, Organization \& Environment 23(1): 32-54. https://doi.org/10.1177/1086026609360324

Etzioni, A. 1994. Spirit of community. Simon and Schuster.

Fainstein, S. S. 2000. New directions in planning theory, Urban Affairs Review 35(4): 451-478. https://doi.org/10.1177/107808740003500401

Fedi, A.; Mannarini, T.; Rovere, A. 2012. Beyond protest: community changes as outcomes of mobilization, Advances in Psychology Study 1(1): 22-30. 
Farrell, M. B. 2009. What is the ACORN controversy about? [online], [cited November 2015]. The Christian Science Monitor online. Available from Internet: http://www.csmonitor. com/USA/Politics/2009/0916/what-is-the-acorn-controversy-about

Foldvary F. E. 1994. Public goods and private communities. The market provision of social services. Aldershot Hempshire: Elgar Pubblication.

Foldvary, F. E. 2001. The completely decentralized city: the case for benefits based public finance, American Journal of Economics and Sociology 60(1): 403-418. https://doi.org/10.1111/1536-7150.00067

Foldvary, F. E. 2002. Small-group, multi-level democracy: implications of Austrian public choice for governance structure, The Review of Austrian Economics 15(2-3): 161-174. https://doi.org/10.1023/A:1015762504055

Gallent, N.; Ciaffi D. (Eds.) 2014. Community action and planning: contexts, drivers and outcomes. Bristol: Policy Press.

Geissler, J. B.; Tricarico, L.; Vecchio, G. 2017. The construction of a tradingzone as political strategy: a review of London Infrastructure Plan 2050, European Journal of Spatial Development 64: 1-22.

Giddens, A. 1998. The third way: the renewal of social democracy. Cambridge: Polity Press.

Greyl, L.; Healy, H.; Leonardi, E.; Temper, L. 2012. Stop that train! Ideological conflict and the TAV, Economics and Policy of Energy and the Environment 2012(2): 193-218.

Gilchrist, A. 2004. A well-connected community. Bristol, UK: The Policy Press.

Goulden, M.; Bedwell, B.; Rennick-Egglestone, S.; Rodden, T.; Spence, A. 2014. Smart grids, smart users? The role of the user in demand side management, Energy Research \& Social Science 2: 21-29. https://doi.org/10.1016/j.erss.2014.04.008

Habermas, J. 1984. The theory of communicative action. Part 1: Reason and the rationalization of society. Boston: Beacon.

Hayek, F. A. 1948. “The Facts of Social Science”, in Individualism and economic order. Chicago: University of Chicago Press.

Hayek, F. A. 1960. The constitution of liberty. Chicago: University of Chicago.

Hayek, F. A. 1988. The fatal conceit: the errors of socialism (Vol. 1). University of Chicago Press. https://doi.org/10.7208/chicago/9780226321158.001.0001

Harsanyi, J. C. 1979. Bayesian decision theory, rule utilitarianism and arrow's impossibility theorem, in A. Diekmann, P. Mitter (Eds.). Paradoxical effects of social behavior. Verlag. https://doi.org/10.1007/bf00126382

Jacobs, J. 1961. The death and life of great American cities. Vintage.

Holman, N.; Rydin, Y. 2004. Re-evaluating the contribution of social capital in achieving sustainable development, Local Environment 9(2): 117-133. https://doi.org/10.1080/1354983042000199561

Kozeny, G. 1995. Intentional communities: lifestyles based on ideals, in Communities directory: a guide to cooperative living. Rutledge, MO: Fellowship for Intentional Community, 18-24.

Leopold, A. 1949. The land ethic. USA, 201-214.

Le Xuan, S.; Tricarico, L. 2014. Imprese comuni: Community Enterprises e rigenerazione urbana nel Regno Unito. Santarcangelo di Romagna: Maggioli editore.

Levinson, D.; Christensen, K. 2003. Encyclopedia of community: from the village to the virtual world (Vol. 2). Sage.
Lindblom, C. E. 1959. The science of "muddling through", Public Administration Review 79-88.

https://doi.org/10.2307/973677

Littera, G.; Sartori, L.; Dini, P.; Antoniadis, P. 2014. From an idea to a scalable working model: merging economic benefits with social values in Sardex, in Inaugural WINIR Conference, 11-14 September 2014, Greenwich, London, UK [online], [cited November 2015]. Available from Internet: http://eprints.lse.ac.uk/59406/

Locke, J. 1690. An essay concerning human understanding [online], [cited April 2017]. Available from Internet: http:// www.gutenberg.org/browse/authors/l\#a2447

Lowi, A.; MacCallum, S. 2014. Community technology: liberating community development, in S. Moroni, D. Andersson (Eds.). Cities and private planning. Cathelham: Edward Elgar Publishing, 106-134. https://doi.org/10.4337/9781783475063.00013

MacIntyre, A. 1984. After virtue (Vol. 99). Notre Dame: University of Notre Dame Press.

MacCallum, S. 1970. The art of community. Institute for Humane Studies.

Messaoudène, M.; Pinson, D.; Berra, M. 2014. Associative action in urban planning: cases studies from Marseille, France, in N. Gallent, D. Ciaffi (Eds.). 2014. Community action and planning. Bristol: Policy Press, 97-115. https://doi.org/10.1332/policypress/9781447315162.003.0006

Mill, J. S. 2010. Utilitarianism. Broadview Press. https://doi.org/10.4135/9781412957397.n351

Minora, F. 2008. The relevance of common lands in building cultural landscapes: the case of Cento (Italy) [online], [cited November 2015]. Available from Internet: http://dlc.dlib. indiana.edu/dlc/handle/10535/1162

Moroni, S. 2014. Towards a general theory of contractual communities: neither necessarily gated, nor a form of privatization, in D. E. Andersson, S. Moroni (Eds.). Cities and private planning: property rights, entrepreneurship and transaction costs. Edward Elgar Publishing.

https://doi.org/10.4337/9781783475063.00010

Moroni, S. 2010. Comunità contrattuali, beni pubblici e ruolo dello Stato, in F. E. Foldvary (Ed.). Beni Pubblici e Comunità Private. Torino: IBL Libri, 7-16.

Moroni, S. 1997. Etica e territorio: Prospettive di filosofia politica per la pianificazione territoriale. Milano: Franco Angeli.

Moore, T.; McKee, K. 2014. The ownership of assets by placebased community organisations: political rationales, geographies of social impact and future research agendas, Social Policy and Society 13(04): 521-533. https://doi.org/10.1017/S1474746413000481

Nelson, H. 2005. Private neighborhoods. Washington: Urban Institute Press.

Nozick, R. 1974. Anarchy, state, and utopia (Vol. 5038). Basic books.

Ostrom, E. 1990. Governing the commons: the evolution of institutions for collective action. Cambridge university press. https://doi.org/10.1017/cbo9780511807763

Ostrom, E. 2000. Social capital: a fad or a fundamental concept, Social capital: a multifaceted perspective 172(173): 195-98.

Ostrom, E. 2010. Beyond markets and states: polycentric governance of complex economic systems, The American Economic Review 641-672.

https://doi.org/10.1257/aer.100.3.641 
Pearce, J. 2003. Social enterprise in anytown. London: Calouste Gulbenkian Foundation.

Phillips, R.; Pittman, R. 2014. An introduction to community development. Routledge.

Pigou, A. C. 1920. The Economics of Welfare. London: Macmillan.

Popper, K. 1944. The poverty of historicism, II. A criticism of historicist methods, Economica 11(43): 119-137.

Pollock, L. 1996. The free society. Westview Press.

Rajagopalan, S.; Tabarrok, A. 2014. Lessons from Gurgaon, India's private city, in D. E. Andersson, S. Moroni (Eds.). Cities and private planning: property rights, entrepreneurship and transaction costs. Edward Elgar Publishing. https://doi.org/10.4337/9781783475063.00018

Rathke, W. 2009. Understanding ACORN. The people shall rule: $A C O R N$, community organizing, and the struggle for economic justice. Nashville, TN: Vanderbilt University Press, $40-62$.

Rydin, Y. 2014. Communities, networks and social capital, in N. Gallent, D. Ciaffi (Eds.) 2014. Community action and planning: contexts, drivers and outcomes. Bristol: Policy Press, 21-39. https://doi.org/10.1332/policypress/9781447315162.003.0002

Rydin, Y.; Pennington, M. 2000. Public participation and local environmental planning: the collective action problem and the potential of social capital, Local environment 5(2): 153-169. https://doi.org/10.1080/13549830050009328

Sandel, M. 1982. Liberalism and the limits of justice. Cambridge University Press, 55-57.

Sassen, S. 2001. The global city: New York, London, Tokyo. Princeton University Press. https://doi.org/10.1515/9781400847488

Sen A. 1990. Individual freedom as a social commitment. Turin: Giovanni Agnelli Foundation.

Sen, A. 1977. On weights and measures: informational constraints in social welfare analysis, Econometrica: Journal of the Econometric Society 1539-1572. https://doi.org/10.2307/1913949
Shaffer, R.; Deller, S.; Marcouiller, D. 2004. Community economics: linking theory and practice (No. Ed. 2). Blackwell Publishing.

Shiell, A.; Hawe, P. 1996. Health promotion community development and the tyranny of individualism, Health Economics 5: 241-247. https://doi.org/10.1002/(SICI)1099_ 1050(199605)5:3<241::AID-HEC197>3.0.CO;2-G

Somerville, P.; McElwee, G. 2011. Situating community enterprise: a theoretical exploration, Entrepreneurship \& Regional Development 23(5-6): 317-330. https://doi.org/10.1080/08985626.2011.580161

Smith, B. 2010. Acorn folds [online], [cited November 2015]. Politico.com. Available from Internet: http://www.politico. com/blogs/ben-smith/2010/03/acorn-folds-025963

Stein, A. 1986. Between organization and movement: ACORN and the Alinsky model of community organizing, Berkeley Journal of Sociology 31: 93-115.

Swyngedouw, E. 2011. Interrogating post-democratization: reclaiming egalitarian political spaces, Political Geography 30(7): 370-380. https://doi.org/10.1016/j.polgeo.2011.08.001

Tricarico, L. 2016. Imprese di comunità come fattore territoriale: riflessioni a partire dal contesto italiano, CRIOS 11: 35-50. https://doi.org/10.3280/CRIOS2016-011004

Unger, R. M. 1976. Knowledge and politics. Simon and Schuster.

Von Pufendorf, S.; Hert, J. N. 1715. De jure naturae et gentium, libri octo (Vol. 1).

Woodin, T.; Crook, D.; Carpentier, V. 2010. Community and mutual ownership: an historical review. York: Joseph Rowntree Foundation.

\section{LUCA TRICARICO}

PhD candidate in Urban Planning, Design and Policy at Politecnico di Milano (DASTU) and Research Fellow at Giangiacomo Feltrinelli Foundation. His research interests include the analysis of community development, innovation, and organizational issues in urban, regional and energy policies. 